\title{
FALHAS NO INÍCIO DO RECONHECIMENTO JURÍDICO DO DOMÍNIO PRIVADO ABSOLUTO SOBRE TERRAS NO BRASIL: Estudo para Melhor Compreensão da Situação Atual das Terras Devolutas e da Falta de Presunção Absoluta de Veracidade do Registro Imobiliário Comum
}

\author{
FAILURES AT THE BEGINNING OF THE LEGAL RECOGNITION OF THE ABSOLUTE \\ PRIVATE DOMAIN OVER LANDS IN BRAZIL: \\ A Study for a Better Understanding of the Current Situation of Untitled Public Lands and the \\ Absolute Lack of Presumption of Truthfulness of Common Real Estate Registry
}

Cláudio GRANDE JUNIOR*

\section{RESUMO:}

O artigo aborda falhas da Lei de Terras do Império, de 1850, e de seu Regulamento, de 1854, que concorreram decisivamente para a formação do atual quadro fundiário brasileiro, de ocultação de considerável parte das terras devolutas por registros imobiliários de conteúdo inverídico, porque certificam propriedades privadas sem origem válida. Falhas relacionadas ao reconhecimento jurídico do domínio privado absoluto sobre terras no Brasil, mais exatamente a forma como ele teve início, sem compromisso com a segurança jurídica mínima necessária para uma adequada efetivação do contemporâneo direito abstrato de propriedade sobre a terra. São analisadas principalmente as implicações dos arts. 22 ao 27 do Regulamento da Lei de Terras do Império (Decreto n. ${ }^{\circ} 1.318$, de 1854), associadas à demora do Poder Público em fazer cumprir outras determinações da legislação de terras. Por fim, demonstra-se a perpetuação desses problemas, mesmo após a tardia organização de um sistema registral imobiliário obrigatório.

\section{PALAVRAS-CHAVE:}

Direito Agrário; Terras Devolutas; Propriedade Privada Imobiliária Abstrata; Lei de Terras do Império; Regulamento da Lei de Terras do Império.

\section{ABSTRACT:}

The article deals with failures of the Land Law of the Empire, of 1850, and of its Regulation, of 1854, which contributed decisively to the formation of the current Brazilian land framework, concealing considerable part of untitled public lands by records of real estate registries of untrue content, because certify private properties without valid source. Failures related to the legal recognition of the absolute private domain over lands in Brazil, more exactly the way it began, uncommitted with the necessary minimum legal security for an

\footnotetext{
* Possui graduação em Direito pela Universidade Católica de Goiás (2000), especialização em Direito Administrativo Contemporâneo pelo Instituto de Direito Administrativo de Goiás (2005), especialização em Direito Constitucional pela Universidade Federal de Goiás (2007) e mestrado em Direito Agrário pela Universidade Federal de Goiás (2012). Desde 2003 é Procurador do Estado de Goiás lotado na Procuradoria de Defesa do Patrimônio Público e do Meio Ambiente. Foi professor Substituto da Universidade Federal de Goiás (2007 a 2009). Tem experiência na área do Direito Agrário, especialmente das relações jurídicas dominais sobre a terra e seu histórico; do Direito Público, com ênfase em Direito Constitucional e Administrativo; e na área do Direito Privado, com ênfase no Direito das Coisas. Atua principalmente nos seguintes temas: direito agrário, direito administrativo, advocacia pública, terras estatais e regularização fundiária (Goiânia/GO/Brasil). E-mail: cgrandejr@gmail.com
} 
adequate execution of the contemporary abstract law of ownership over the land. The implications of arts. 22 to 27 of the Regulation of the Land Law of the Empire (Decree no. 1,318 , of 1854) are primarily analyzed, in association with the delay of Public Power to enforce other determinations of the land legislation. Finally, it demonstrates the perpetuation of these problems, even after the late organization of a mandatory real estate registration system.

\section{KEY-WORDS:}

Agrarian Law; Untitled Public Lands; Real Estate Private Property; Land Law of the Empire; Regulation of Land Law of the Empire.

\section{INTRODUÇÃO}

Há tempos, três sérios problemas perturbam os juristas e afligem a sociedade brasileira. Por que ainda existem tantas terras devolutas não identificadas e ocultadas por registros imobiliários inverídicos de propriedade privadas? Por que a maioria das cadeias registrais imobiliárias não retrocede até a origem, indicando a causa da constituição do domínio particular sobre a terra? Como se conseguiu criar um sistema registral imobiliário que, muitas vezes, não expressa a veracidade sobre o domínio privado da terra?

O presente artigo busca algumas respostas para essas indagações, analisando determinadas falhas da legislação de terras do Império, quanto à normatização do início do reconhecimento jurídico do domínio privado absoluto sobre imóveis no Brasil. A hipótese é a de a origem dos problemas residir nessas falhas da Lei de Terras, de 1850, e do seu Regulamento, de 1854, bem como na inércia do Império em concretizar e fazer com que fossem cumpridos os comandos dessa legislação.

A pesquisa foi eminentemente bibliográfica, de busca das interpretações doutrinárias e jurisprudenciais conferidas a esses textos legais no decorrer da história. Mas também foram examinados documentos representativos de situações disciplinadas pela legislação em referência, tais como: registros paroquiais, cartas de sesmarias, certidões sobre autos judiciais de medição e demarcação de sesmarias e títulos na época admitidos como de transferência de domínio de bens de raiz. Fez-se necessária, então, para melhor compreensão desses documentos, a leitura de livros e artigos de outras áreas, como história, geografia e economia.

O método de abordagem inicialmente utilizado na condução da investigação foi o hipotético-dedutivo. Contudo, ele se mostrou insuficiente para uma satisfatória compreensão 


\section{FALHAS NO INÍCIO DO RECONHECIMENTO JURÍDICO [...]}

dos vetustos diplomas legais e das respectivas interpretações doutrinárias e jurisprudenciais. O método indutivo se revelou mais adequado para a formação de sentido aos resultados da análise do material documental colhido. Por fim, revelou-se inevitável a investigação histórica de acontecimentos políticos, econômicos e sociais para uma compreensão minimamente aceitável do fenômeno jurídico em foco, principalmente quanto ao enfrentamento das divergências encontradas no material bibliográfico e no documental. Neste ponto foi imprescindível a utilização do método dialético para superação das contradições.

Embora não explicitamente mencionado no decorrer do trabalho, o principal referencial teórico utilizado é o proposto por Niklas Luhmann de compreensão do direito como subsistema social autopoiético. Luhmann (2002, p. 327 a 329) entende que a simples previsão e garantia jurídica da propriedade da terra não conduz, por si só, a uma ordem econômica baseada num mercado imobiliário seguro. A sociedade e a economia devem alcançar determinado patamar, para proporcionar o material problemático e a casuística com que o sistema jurídico há de se confrontar e se irritar para, consequentemente, se desenvolver. Outro norte de orientação deste trabalho foi a tese de Laura Beck Varela (2005) sobre a transição, no Brasil, da propriedade fundamentada pelo cultivo para a propriedade abstrata da terra. Por fim, também serviu de orientação no desenvolvimento do texto a distinção entre domínio e propriedade proposta por Ricardo Aronne (1999).

\section{SITUAÇÃO JURÍDICA DAS TERRAS NO BRASIL DURANTE O ANTIGO REGIME}

Antes da chegada definitiva dos europeus na América do Sul, as terras onde hoje se situa o Brasil eram dominadas e utilizadas pelas comunidades indígenas por modos outros bastante diferentes do instituto jurídico da propriedade privada abstrata, que atualmente regula, na maciça maioria dos casos, as relações entre os homens tendo por objeto o domínio da terra. Carlos Frederico Marés (2003, p. 50) explica que a apropriação individual era restrita aos bens de uso pessoal, eventualmente ao produto do trabalho individual. A terra sempre era um bem coletivo e a repartição haveria de ser dos frutos da terra. "Não havia necessidade de Estado nem de teorias sobre a propriedade privada, nem instrumentos que justificassem seu exercício, nem que os garantisse".

Do mesmo modo, os europeus, quando chegaram à América, ainda não tinham uma mentalidade formada que admitisse a instituição da propriedade privada moderna sobre a terra. Viviam o mercantilismo, sob as rédeas dos Estados absolutistas. No caso de Portugal, o 
historiador Manuel Nunes Dias (1963, p. 359) acentua que só a Coroa, e mais ninguém, dirigia o empreendimento, que era seu monopólio e inalienável, inclusive as novas terras descobertas, que, como se fossem conquistadas, pertenciam, de direito e de fato, à monarquia.

Se, por um lado, os índios tentavam defender as terras como um bem coletivo da tribo; por outro, os conquistadores portugueses procuravam ocupá-las em nome da Coroa, porque tudo o que fosse descoberto pertencia ao patrimônio da realeza e esse patrimonialismo foi um princípio que se imiscuiu no ordenamento jurídico do sistema colonial. Então, durante a conquista e colonização portuguesa, não havia que se falar em propriedade privada da terra. À medida que avançava pela América, o Estado Português, confundindo-se com sua Coroa, adquiria o domínio de todas as terras que suas armas protegiam.

Todavia, incapaz de explorar diretamente as vastas extensões de terras descobertas, a Coroa concedia o direito de exploração de porções das mesmas através do instituto jurídico das sesmarias.

É muito citada a deturpada aplicação do instituto das sesmarias em terras brasileiras. Entretanto, antes mesmo da descoberta do Brasil pelos portugueses, o instituto sofrera progressivas transformações. Além disso, as Ordenações Manuelinas, de 1521 (Liv. IV, tít. $67, \S \S 8^{\circ}$ e 14 ), proibiam quaisquer pessoas de se apropriarem, para si ou para as ordens e entidades religiosas, dos matos maninhos ou das matas e bravios que nunca foram lavrados e aproveitados, mandando deixá-los aos sesmeiros, para que estes verificassem se podiam ser dados em sesmarias. Reside aí a norma que proibia a aquisição do domínio particular por ocupação e impedia a usucapião ou a prescrição aquisitiva sobre as novas terras conquistadas pela Coroa Portuguesa no ultramar, inclusive no Brasil (GRANDE JÚNIOR, 2012, p. 281). As Ordenações Filipinas, de 1603, só repetiram tal disciplina jurídica. Por isso, Ruy Cirne Lima vislumbrou inevitável o transplante do instituto das sesmarias para as terras achadas por Cabral, "suposto que meio legal diverso não havia para povoamento da imensa gleba, ainda inviolada" (1954, p. 32).

Por exigência do ordenamento jurídico, as cartas de sesmarias previam que as terras poderiam ser retomadas e dadas a outras pessoas, se os concessionários não as aproveitassem em determinado prazo. Contudo, em razão da enorme distância da Europa e das dificuldades opostas pela natureza selvagem e pela resistência indígena, abrandou-se a fiscalização do cultivo no Brasil, até ser completamente negligenciada no século XIX.

Se, na Europa, a sesmaria era direito sobre o uso da terra condicionado à produção, no Brasil surgiu grande polêmica sobre sua natureza, se enfitêutica (JUNQUEIRA, 


\section{FALHAS NO INÍCIO DO RECONHECIMENTO JURÍDICO [...]}

1976, p. 30) (MARQUES, 2009, p. 23), mera concessão administrativa (LIMA, 1954, p. 36 e 39) ou dominial privada nos moldes praticados no direito romano, desde que cumpridas todas as exigências legais (PORTO, 1979, p. 114). Por evitar anacronismos, a melhor tese parece ser a de Laura Beck Varela (2005, p. 69 e 75): "forma de propriedade essencialmente condicionada" ao cultivo, uma dentre as múltiplas formas dominais da sociedade portuguesa da época, mas que se tornou regra geral no Brasil. “ [...] uma propriedade não-absoluta, cuja condição sine qua non, razão de ser, reside no dever de cultivar".

Assim, mesmos as sesmarias validamente demarcadas, medidas e confirmadas não podiam ser consideradas propriedades imobiliárias na acepção da abstrata propriedade moderna de molde napoleônico-pandectístico, porque tinham por fundamento o cultivo e a efetiva continuidade dele. Bastante elucidativas as palavras de Laura Beck Varela, ao discorrer que a sesmaria "permanece, em essência, uma forma de propriedade condicionada, não-absoluta” (2005, p. 55): “Não se tratava, portanto, de ‘domínio' ou 'posse’ abstratamente considerados, mas de domínio adjetivado pelo atributo da utilidade.” (2005, p. 59). É verdade que a fiscalização do cultivo no Brasil, na prática, foi muito precária. Porém, estava formal e inequivocamente prevista no ordenamento jurídico.

A instituição formal da propriedade privada absoluta sobre a terra, independente desse dever de cultivo, só seria consagrada muito depois, com a Lei de Terras do Império, de 1850, e seu Regulamento, de 1854.

Antes, a prática do apossamento não autorizado de terras aniquilaria as sesmarias como modo usual de acesso à terra. É bom lembrar que essas posses, além de irregulares, eram ilegais, uma vez que as Ordenações Manuelinas e as Ordenações Filipinas não permitiam a apropriação e nem mesmo o apossamento espontâneo de terras da Coroa por particulares. Todavia, em meados do século XVIII, o sistema sesmarial já se mostrava defasado ante a realidade da multiplicidade de posses e, nos embates judiciais, as sesmarias sucumbiam perante as posses com cultura efetiva. Esse quadro contribuiu para o príncipe regente Dom Pedro suspender a concessão de novas sesmarial aos 17 de julho de 1822 .

Poucos meses depois, foi declarada a independência do Brasil. As terras da Coroa Portuguesa passaram ao domínio do Império do Brasil. A legislação portuguesa então em vigor, inclusive as Ordenações Filipinas, foram recepcionadas e o regime sesmarial permaneceu suspenso. Com a Constituição Imperial de 1824 começaram as mudanças, mas ainda muito lentamente, porque, embora tivesse previsto o direito fundamental à propriedade, nada dispôs sobre sua regulamentação em se tratando de imóveis, nem sobre o necessário processo de privatização das terras do Império. Também houve inércia do Poder Legislativo 
na normatização desses pontos, porque os parlamentares não alcançavam um consenso mínimo sobre os modos de aquisição da propriedade imobiliária. Se já era trabalho corriqueiro dos colonos apoderarem-se de terras da Coroa e cultivá-las, o vácuo normativo que acompanhou a suspensão do regime sesmarial conduziu à inevitabilidade de tal prática, no período que se estendeu de 1822 a 1850 e ficou conhecido como "extralegal" ou "das posses". Ainda não havia possibilidade jurídica de usucapião ou prescrição aquisitiva dessas terras, porque o regime sesmarial não fora revogado, mas apenas suspenso. Aliás, da Resolução de 17 de julho de 1822 e da Provisão de 22 de outubro de 1823, verifica-se que não exatamente o regime sesmarial como um todo fora suspenso, mas tão somente "que se suspendessem todas as sesmarias futuras" (JUNQUEIRA, 1976, p. 69 e 71.).

Por fim, evitando brigar com a realidade consolidada, a Lei de Terras de 1850 possibilitou o reconhecimento jurídico do domínio privado absoluto sobre boa parte das terras que, naquele momento, se encontravam possuídas e cultivadas por particulares. Todavia, a forma atrapalhada como o Regulamento de 1854 disciplinou isso, somada à inércia do Poder Público em identificar e delimitar as terras que, naquela ocasião, não eram possuídas por particulares, legou para as gerações futuras o problema, cada vez mais difícil de solucionar, da identificação e delimitação das terras devolutas.

2. INÍCIO DA NORMATIZAÇÃO DA MODERNA PROPRIEDADE PRIVADA DA TERRA NO BRASIL: CONSTITUIÇÃO IMPERIAL DE 1824, LEI DE TERRAS DO IMPÉRIO (LEI N. ${ }^{\circ}$ 601, DE 1850) E SEU REGULAMENTO (DECRETO N. ${ }^{\circ}$ 1.318, DE 1854)

Carlos Frederico Marés (2003, p. 17-28) comenta que a ideia de apropriação individual, exclusiva e absoluta de uma gleba de terras é construção humana localizada e recente. A concepção atual da propriedade foi construída ao longo do mercantilismo, por trezentos anos de elaboração teórica controvertida e incerta. John Locke foi um dos decisivos pensadores da propriedade contemporânea. Até então, a civilização cristã entendia a propriedade como uma utilidade, um utendi. A partir de Locke, e na construção capitalista, começou a ser um direito subjetivo independente. Voltaire afirmou que a propriedade é liberdade e considerou a propriedade da terra um direito natural e necessário ao bem estar de todos. O reconhecimento de liberdades individuais na Inglaterra do século XIII ao XVII, que possibilitaram a Revolução Industrial a partir da segunda metade do século XVIII, a 


\section{FALHAS NO INÍCIO DO RECONHECIMENTO JURÍDICO [...]}

independência dos Estados Unidos da América, a Revolução Francesa ao final do mesmo século e a elaboração das Constituições nacionais, a partir de então, foram marcos jurídicos da propriedade moderna. "O Estado moderno foi teoricamente construído para garantir a igualdade, a liberdade e a propriedade." (MARÉS, 2003, p. 18). Ao mesmo tempo, criou-se o instituto da desapropriação, uma forma de confirmação da propriedade, porque, no caso de retirada compulsória desta, obrigava o Estado ao pagamento de uma indenização equivalente.

Envolvidos por essa nova conjuntura, os juristas luso-brasileiros do final século XVIII e início do século XIX assimilaram a "mentalidade proprietária moderna", como engrenagem de um contexto maior de livre mercado, e afastaram decididamente o cultivo do “conteúdo proprietário". Desse modo, encaravam as sesmarias com perplexidade, como uma instituição arcaica atentatória aos direitos individuais (VARELA, 2005, p. 215-216). “O instituto jurídico das sesmarias encontrou o seu fim, não por uma deliberação isolada do governante da época, mas por sua absoluta incompatibilidade com o novo sistema jurídico estruturado no final do século XVIII e começo do XIX.” (MARÉS, 2003, p. 63).

A Constituição Imperial de 1824, lei fundamental desse novo sistema jurídico, garantiu o direito de propriedade, pleno e absoluto, no seu art. 179:

XXII. E'garantido o Direito de Propriedade em toda a sua plenitude. Se o bem publico legalmente verificado exigir o uso, e emprego da Propriedade do Cidadão, será elle préviamente indemnisado do valor della. A Lei marcará os casos, em que terá logar esta unica excepção, e dará as regras para se determinar a indemnisação.

O direito de propriedade estava estabelecido na Constituição de 1824, mas, conforme já no explicado na seção anterior, não havia previsão legal de como ocorreria a efetiva transferência de domínio absoluto das terras do Império para os particulares. Enquanto isso não acontecia, as pessoas não podiam adquirir o direito abstrato de propriedade, como concebido hoje, sobre as terras localizadas em território brasileiro, muito menos comercializálos regularmente, o que dificultava também o oferecimento de direitos reais de garantia sobre imóveis. Mesmo os titulares de sesmarias confirmadas não tinham exatamente um domínio absoluto da terra, porque condicionado à continuidade do cultivo. Assim, por mais estranho que isso possa parecer hoje, o direito constitucional à plena propriedade tinha pouca efetividade com relação a imóveis até meados do século XIX. O direito de propriedade contemporâneo assegurado pela Constituição Imperial enfrentava, quanto aos bens imóveis, uma situação parecida com a vivenciada, hoje, da baixa efetividade de certos direitos sociais previstos na Constituição de 1988 (GRANDE JÚNIOR, 2012, p. 359-360). 
Procurou-se solucionar esse grave problema com a promulgação da Lei de Terras do Império (Lei n. ${ }^{\circ}$ 601, de 1850). Laura Beck Varela sintetiza o feixe de situações que a lei teve que enfrentar e normatizar, nesse período de transição das situações de posse e de domínio condicionado para a de domínio absoluto (2005, p. 117):

\begin{abstract}
O quadro fundiário brasileiro caracteriza-se, assim, por um complexo de situações, que só mais tarde seriam reguladas pela Lei $\mathrm{n}^{\circ}$ 601, de 1850. Havia sesmarias concedidas e integralmente regularizadas - demarcadas, confirmadas e aproveitadas (cultura ou criação), sobre as quais o concessionário tinha domínio sobre a gleba. Havia também as sesmarias em que os concessionários tinham só a posse, e não o domínio, pela ausência de algumas exigências legais. Também as glebas ocupadas por simples posses, sem título, eram situações de fato; ocupações com ou sem exploração. E, por fim, as terras sem ocupação (terras devolutas do império) - "não concedidas ou já revertidas ao poder público, por não atendimento das exigências legais, se anteriormente objeto de concessão de semarias".
\end{abstract}

A Lei de Terras disciplinou cada uma dessas situações. Contudo, ela não teve imediata aplicação, porque não foi logo regulamentada, dadas as dificuldades do Governo em tentar contemplar interesses de difícil conciliação (SILVA, 1996, p. 167). A execução da lei só se tornou possível a partir de 1854 , quando foi editado o Decreto n. ${ }^{\circ} 1.318$, que baixou o Regulamento da Lei de Terras. Analisando-o, parece que algumas soluções adotadas visaram reconhecer o domínio absoluto a determinados fazendeiros, da forma menos onerosa possível, descurando-se da segurança jurídica mínima exigível para a constituição da propriedade imobiliária em um título oponível contra todos, inclusive o Estado, o que possibilitou a perpetração de fraudes e o fenômeno da grilagem de terras.

\title{
3. FALHAS NA NORMATIZAÇÃO DA PROPRIEDADE PRIVADA ABSTRATA CONSTITUÍDA SOBRE SESMARIAS E OUTRAS CONCESSÕES NÃO INCURSAS EM COMISSO
}

A Lei Imperial de Terras alçou, da natureza de domínio condicionado ao cultivo à de domínio privado alodial absoluto, as sesmarias que, naquele momento, não se encontravam incursas em comisso por falta do cumprimento das condições de medição, confirmação e cultura. Fez o mesmo com outras concessões governamentais já confirmadas e que não se encontravam em comisso por falta de medição ou cultura (art. $3^{\circ}, \S 2^{\circ}$, segunda parte). Reconheceu-se, portanto, o domínio privado absoluto, a ser instrumentalizado pela propriedade privada abstrata, sobre essas terras. 
Art. $3^{\circ}$ São terras devolutas:

$[\ldots]$

$\S 2^{\circ}$ As que não se acharem no dominio particular por qualquer titulo legitimo, nem forem havidas por sesmarias e outras concessões do Governo Geral ou Provincial, não incursas em commisso por falta do cumprimento das condições de medição, confirmação e cultura. [sublinhou-se]

Pode-se imaginar que as cartas de confirmação dessas sesmarias e concessões se transformaram, automaticamente, de título de domínio dependentes da concreta demonstração de cultivo em títulos de domínio abstraídos do cultivo, absolutos e irreversíveis sobre a respectiva terra. Todavia, esses documentos não conferiam a inteira segurança jurídica exigível para a efetividade do direito de propriedade em termos abstratos. Isso porque a documentação sobre concessão, registro, demarcação, medição e confirmação das sesmarias não se encontrava reunida toda numa única repartição, muito pelo contrário. Por causa disso, com o passar do tempo, a verificação da demarcação, da confirmação e da posterior inaplicação da pena de comisso por falta de continuidade do cultivo foi se tornando cada vez mais complicada. Hoje, pelo menos no Estado de Goiás, não é fácil conferir se um título atual de propriedade sucede de uma sesmaria devidamente demarcada, medida, confirmada e em cultivo na década de 1850, quando foram aplicadas as disposições concernentes da Lei de Terras do Império e de seu Regulamento. Nos arquivos do Estado há apenas as cartas de concessão das sesmarias.

O ideal seria o Império ter emitido títulos de propriedade em substituição a toda essa documentação esparsa, comprovadora de que a sesmaria fora demarcada, confirmada e não se encontrava em comisso por falta de cultivo. Todavia, a Lei de Terras foi omissa quanto a tal ponto. O Regulamento, pior ainda, estatuiu expressamente ao contrário:

\footnotetext{
Art. 23. Estes possuidores, bem como os que tiverem terras havidas por sesmarias, e outras concessões do Governo Geral, ou Provincial não incursas em commisso por falta de cumprimento das condições de medição, confirmação, e cultura, não tem precisão de revalidação, nem de legitimação, nem de novos titulos para poderem gozar, hypothecar, ou alienar os terrenos, que se achão no seu dominio. [sublinhouse]
}

Entretanto, esse foi o menor dos problemas criados pelo Regulamento, porque os casos de sesmarias e outras concessões confirmadas eram os que menos se verificavam na prática. A maioria era de sesmarias não confirmadas e de terras de algum outro modo 
possuídas por particulares. Pesquisas feitas na região norte do país demonstram que das 2.158 sesmarias expedidas na Capitania do Grão-Pará entre 1700 e 1835, apenas 556 foram confirmadas (ÉLERES, p. 144 apud VARELA, 2005, p. 97). Em Goiás, segundo Maria do Amparo Albuquerque Aguiar (2003, p. 60 e 63), entre os mais de mil pedidos e concessões de sesmarias, datados de 1726 a 1770, foram encontradas apenas 12 confirmações. Além disso, a totalidade das sesmarias simplesmente concedidas cobria diminuta extensão do território goiano.

\section{EXCESSIVO ALARGAMENTO DA NOÇÃO DE TÍTULO LEGÍTIMO DE DOMÍNIO ADMITIDO PELA LEI DE TERRAS}

Se a segunda e maior parte do texto do $\S 2^{\circ}$ do art. $3^{\circ}$ da Lei de 1850 cuidava das terras que se encontravam no domínio particular por sesmarias ou outras concessões não incursas em comisso, a primeira e sucinta parte do dispositivo tratava das terras que estavam no domínio particular por qualquer título naquela ocasião considerado legítimo.

\footnotetext{
Art. $3^{\circ}$ São terras devolutas:

$[\ldots]$

$\S 2^{\circ}$ As que não se acharem no dominio particular por qualquer titulo legitimo, nem forem havidas por sesmarias e outras concessões do Governo Geral ou Provincial, não incursas em commisso por falta do cumprimento das condições de medição, confirmação e cultura. [sublinhou-se]
}

À vista do que se argumentou nas seções anteriores, emerge inevitável uma pergunta: além das documentações de sesmarias e demais concessões estatais não incursas em comisso, quais outros documentos, naquele instante, poderiam ser considerados "títulos legítimos" de aquisição do domínio pelo particular? Mais uma vez, a Lei de Terras silencia. Dispondo sobre hipótese contrária, o $\S 4^{\circ}$ do mesmo artigo apenas auxilia na interpretação sistemática da lei, ao exigir a legitimação das posses que não se fundavam em "titulo legal".

Coube ao Regulamento disciplinar a questão: “Art. 25. São titulos legitimos todos aquelles, que segundo o direito são aptos para transferir o dominio.”.

Nesse ponto, cumpre advertir que, na época, ainda vigoravam as Ordenações Filipinas, que não exigiam registro em cartório imobiliário para a transferência do domínio da terra. A aquisição do domínio de imóveis era muito parecida com a de móveis e se operacionalizava em grande medida pela tradição, ou seja, com a entrega da coisa pelo R. Fac. Dir. UFG, v. 39, n.1, p. 93 - 125, jan. / jun. 2015 


\section{FALHAS NO INÍCIO DO RECONHECIMENTO JURÍDICO [...]}

alienante ao adquirente. A transferência do domínio se dava por juridicamente perfeita e acabada com a tradição do imóvel, acompanhada ou precedida de título hábil (Ordenações Filipinas, Liv. IV, títulos iniciais, principalmente o título $5^{\circ}$, e, posteriormente, Consolidação Teixeira de Freitas, art. 908). Reputavam-se títulos hábeis os contratos, as disposições de última vontade e as decisões judiciais. Devido ao baixíssimo valor de negociação das terras brasileiras, nem sempre o contrato precisava se corporificar numa escritura pública. Por outro lado, sentenças de inventário e decisões de arrematação eram títulos hábeis a transferir o domínio, bastando que o interessado tomasse as providências para obter a posse do bem, sem necessidade, como hoje, de se promover o registro imobiliário das mesmas.

Para as transferências de domínio posteriores à Lei de Terras é fácil visualizar tais títulos: eram todos aqueles aptos a transferir sesmarias e outras concessões estatais não incursas em comisso, bem como para transferir títulos através dos quais o Estado, daquele momento em diante, revalidaria sesmarias, legitimaria posses ou venderia terras.

Mas a verdade é que essa face da lei se volta para o passado, ou seja, aos títulos anteriores à sua vigência. Enquadram-se aí os títulos emitidos entre particulares, transferindo direitos sobre sesmarias ou outras concessões não incursas em comisso. Com isso, a Lei de Terras reconhecia o domínio a quem, não sendo o sesmeiro ou o concessionário originalmente confirmado, tivesse destes adquiridos os direitos sobre a sesmaria ou outra concessão governamental não incursa em comisso. Assim, sem dificuldades, consegue-se encaixar como títulos legítimos de domínio anteriores à vigência da Lei de Terras esses de transferência de sesmarias e de outras concessões governamentais não incursas em comisso.

Mas, além de ter outorgado direitos às terras por sesmarias e outras modalidades de concessões, poderia o Estado, por outros meios, ter anteriormente alienado aos particulares o domínio de terras localizadas no Brasil? Caso a resposta seja afirmativa, foi algo muito incomum, porque nenhuma referência a exemplos concretos foi encontrada durante as pesquisas para elaboração deste artigo científico. Porém, a reposta mais provável é a negativa, porque parece contrariar a normatização das Ordenações.

Lígia Osorio Silva (1996, p. 167) comenta que o Regulamento foi previsível em alguns aspectos e surpreendente em outros. Aos olhos do intérprete de hoje, um dos pontos mais surpreendentes é o do admissão de títulos de aquisição de posse como títulos de aquisição de domínio. E um dos mais difíceis de compreender, dado o sutil jogo de palavras estabelecido entre a Lei de Terras e seu Regulamento, a partir do seguinte dispositivo do último: 
Art. 22. Todo o possuidor de terras, que tiver titulo legitimo da acquisição do seu dominio, quer as terras, que fizerem parte delle, tenhão sido originariamente adquiridas por posses de seus antecessores, quer por concessões de sesmarias não medidas, ou não confirmadas, nem cultivadas, se acha garantido em seu dominio, qualquer que for a sua extensão, por virtude do disposto no $\S 2^{\circ}$ do Art. $3^{\circ}$ da Lei $n^{\circ}$ 601 de 18 de Setembro de 1850, que exclue do dominio publico, e considera como não devolutas, todas as terras, que se acharem no dominio particular por qualquer titulo legitimo.

Tal dispositivo reconheceu o domínio pleno a todo possuidor de terras que tivesse adquirido sua posse por algum titulo que, pela legislação da época, também fosse hábil à aquisição do domínio. O domínio era reconhecido por tal fórmula tanto em terras concedidas por sesmarias não medidas, ou não confirmadas, nem cultivadas, como até mesmo em terras que tinham sido originariamente adquiridas por simples posses dos antecessores. Para tanto, bastava que o segundo ocupante ${ }^{1}$ tivesse adquirido a posse do anterior por título que também fosse apto à transferência do domínio (GRANDE JÚNIOR, 2012, p. 362).

Exemplificando, uma porção de terras fora concedida em sesmaria nunca medida nem confirmada, mas o agraciado permaneceu na posse das terras e posteriormente vendeu-as para outra pessoa, formalizando o contrato por meio de uma escritura pública. Esta era considerada, pelo Regulamento, não apenas um título de aquisição de posse, mas um título de aquisição de domínio. Do mesmo modo o escrito particular, quando o valor do contrato permitisse que fosse celebrado com tal simplicidade, desde que recolhido tempestivamente o respectivo tributo. O Regulamento fez questão de não pairar dúvida sobre isso:

Art. 26. Os escriptos particulares de compra e venda, ou doação, nos casos em que
por direito são aptos para transferir o dominio de bens de raiz, se considerão
legitimos, se o pagamento do respectivo imposto tiver sido verificado antes da
publicação deste Regulamento: no caso porêm de que o pagamento se tenha
realisado depois dessa data, não dispensarão a legitimação, se as terras transferidas
houverem sido adquiridas por posse, e o que as transferir tiver sido o seu primeiro
occupante.

Outra situação bastante comum, conforme relatam os registros paroquiais em Goiás, era a de o desbravador e primeiro possuidor falecer e se formalizar na sentença de seu inventário a aquisição da posse pelos herdeiros. Tais sentenças foram igualmente alçadas à categoria de títulos legítimos de aquisição de domínio pelos art. $3^{\circ}, \S 2^{\circ}$, da Lei de Terras e art. 22 do Regulamento.

\footnotetext{
${ }^{1}$ As expressões "ocupante" e "ocupação" serão empregadas, deste ponto em diante do trabalho, sem o sentido técnicojurídico relacionado ao instituto da ocupação, previsto nos arts. 592 e 593 do Código Civil de 1916 e no art. 1.263 do Código Civil de 2002.

R. Fac. Dir. UFG, v. 39, n.1, p. 93 - 125, jan. / jun. 2015

ISSN 0101-7187
} 


\section{FALHAS NO INÍCIO DO RECONHECIMENTO JURÍDICO [...]}

Desse modo, para algumas terras até então meramente possuídas o Regulamento admitiu o domínio particular absoluto, mais exatamente em benefício das pessoas que adquiriram a posse por títulos que, segundo a legislação da época, seriam hábeis também a transferir o domínio. Os casos mais comuns desse tipo de título foram os contratos de compra e venda e as sentenças judiciais de inventário.

É por isso que Cirne Lima (1954, p. 60 e 61) considera a Lei Imperial de Terras uma errata aposta à legislação de sesmarias e, "ao mesmo tempo, uma ratificação formal do regime das posses":

Da mesma sorte, porém, resguarda a lei a situação dos adquirentes, a título legítimo, das terras simplesmente possuídas, já tratando-se de posses pròpriamente ditas, já tratando-se de sesmarias caducas.

Aos títulos legítimos de aquisição de terras nessas circunstâncias, reconhece a lei efeito translativo de domínio, sem cogitar da extensão das terras adquiridas e sem indagar se a posse dos alienantes diretos se teria estabelecido, nas condições da lei ou do costume. [LIMA, 1954, p. 63]

Messias Junqueira (1976, p. 84) tangencia por similar sentir:

E como o propósito principal da lei 601 foi conduzir à titulação quem não tinha título, considerou perfeito o domínio de quem já possuísse um título. Por exemplo, quem adquirisse uma sesmaria, comprando-a ao primeiro sesmeiro, tinha domínio, não se lhe exigindo promover revalidação alguma do seu título. Quem houvesse comprado uma posse, pagando sisa em tempo anterior à vigência da lei, tinha o seu título em ordem, não necessitando legitimar sua posse.

Mais recentemente, Laura Beck Varela (2005, p. 158) comenta que o Regulamento da Lei de Terras "afirma, em seu art. 22, proteção aos possuidores e sesmeiros, os quais seriam garantidos 'em seu dominio', quando 'detentores de qualquer titulo legitimo"”.

Em outras palavras, tais terras que, até então, a rigor, eram meramente possuídas por particulares, foram consideradas no domínio particular. E, o mais grave, sem necessidade de um novo título substitutivo, conforme expressamente dispôs o Regulamento, equiparando esses possuidores aos titulares de sesmarias e outras concessões governamentais não incursas em comisso:

Art. 23. Estes possuidores [os mencionados no art. 22], bem como os que tiverem terras havidas por sesmarias, e outras concessões do Governo Geral, ou Provincial não incursas em commisso por falta de cumprimento das condições de medição, confirmação, e cultura, não tem precisão de revalidação, nem de legitimação, nem 
de novos titulos para poderem gozar, hypothecar, ou alienar os terrenos, que se achão no seu dominio.

O art. 59 do Regulamento não obrigou, apenas facultou aos "proprietários pretenderem obter titulo de sua possessão, passado pela Repartição Geral das Terras Publicas". Neste caso, deveriam primeiramente requer pela, via judicial, "a medição das terras, que se acharem no seu domínio por titulo legitimo" (art. 60). Como passo subsequente, o art. 61 dispunha: "Obtida a sentença de medição, e passada em julgado, os proprietarios poderão solicitar com ella dos Presidentes de Provincia o titulo de suas possessões; e estes o mandarão, passar pela maneira declarada no Art. 51". O artigo aludido ao final era um dos que disciplinavam o meio prático, mas não tão posto em prática, de extremar o domínio público do privado. Completando, a disciplina normativa acima analisada era estendida aos possuidores, por títulos legítimos, de terras dadas por sesmarias caídas em comisso e que não se achavam mais na posse dos concessionários (art. 62).

Em Goiás, a maioria dos registros paroquiais pesquisados faz referência à hipótese do art. 22 do Regulamento. Os declarantes se apresentavam como segundos ocupantes a título legítimo, normalmente por herança ou compra. Mas como o art. 23 do Regulamento não exigiu a expedição de novos títulos em substituição aos antigos, atualmente há uma enorme dificuldade em encontrar os títulos legítimos de aquisição do "domínio" mencionados nos registros paroquiais, principalmente quando documentos particulares.

Outro problema da não obrigatoriedade de retirada de novos títulos foi o de possibilitar, mais tarde, a perpetração de fraudes, consubstanciada na falsificação de títulos de transferência de domínio (a rigor, posse) enquadráveis no Regulamento da Lei de Terras. A prática teve início já logo em seguida ao início da vigência do Regulamento e prosseguiu pelos anos seguintes. Mas com o passar das décadas e, principalmente, a partir do século XX, se tornou necessário o envelhecimento forçado dos documentos falsos, sendo a técnica mais relatada para tanto a da colocação dos papeis dentro de caixas com grilos. Daí a origem da expressão "grilagem de terras".

Concluindo esta seção, os arts. 22, 23, 25 e 26 do Regulamento reconheceram o domínio absoluto a todo possuidor de terras que tivesse adquirido sua posse por algum titulo que, pela legislação da época, também fosse hábil à aquisição do domínio, ainda que essas terras tivessem sido originariamente adquiridas por meras posses de seus antecessores ou por concessões de sesmarias não medidas, ou não confirmadas, nem cultivadas. A não exigência de outorga, em determinado prazo, de novos títulos de domínio substitutivos dos antigos 


\section{FALHAS NO INÍCIO DO RECONHECIMENTO JURÍDICO [...]}

criou, em nossos dias, a dificuldade de comprovação da ocorrência dessa hipótese. Ademais, possibilitou, no decorrer subsequente da história, a perpetração de fraudes mediante a falsificação e envelhecimento de títulos que a Lei de Terras do Império e seu Regulamento consideravam legítimos de aquisição do domínio.

\section{ESTREITAMENTO DAS HIPÓTESES DE LEGITIMAÇÃO DE POSSES E DE REVALIDAÇÃO DE SESMARIAS E OUTRAS CONCESSÕES INCURSAS EM COMISSO}

$\mathrm{O}$ art. $3^{\circ}$ da Lei de Terras definia as terras devolutas por exclusão, estabelecendo quais terras estavam no domínio particular. Consoante analisado acima, seu $\S 2^{\circ}$, com a ajuda do Regulamento, reconheceu que estavam no domínio privado as terras possuídas por qualquer titulo legitimo e as que foram havidas por sesmarias e outras concessões governamentais não incursas em comisso. Mas, além disso, autorizou que outras terras, naquele momento já em posse de particulares, também fossem reconhecidas como transferidas ao domínio privado:

\footnotetext{
$\S 3^{\circ}$ As que não se acharem dadas por sesmarias, ou outras concessões do Governo, que, apezar de incursas em commisso, forem revalidadas por esta Lei.

$\S 4^{\circ}$ As que não se acharem occupadas por posses, que, apezar de não se fundarem em titulo legal, forem legitimadas por esta Lei.
}

Assim, as sesmarias ou outras concessões do Governo Geral, ou Provincial, em situação de descumprimento de algumas exigências com que foram concedidas, poderiam ser revalidadas se estivessem cultivadas, ou com princípios de cultura, e morada habitual do respectivo sesmeiro ou concessionário, ou de quem os representasse (art. $4^{\circ}$ ).

Caso não fossem objeto de sesmaria ou outra concessão, as posses poderiam ser legitimadas, se fossem mansas e pacíficas, decorrentes de apossamentos primários ou havidas do primeiro possuidor, e se encontrassem cultivadas, ou com princípio de cultura, e morada habitual do respectivo posseiro ou de quem o representasse (art. $5^{\circ}$ ).

Todavia, consoante analisado na seção anterior, o Regulamento de 1854 subverteu a interpretação mais aparente ou óbvia $\operatorname{dos} \S \S 2^{\circ}, 3^{\circ}$ e $4^{\circ}$ do art. $3^{\circ}$ da Lei de Terras, ao conferir um espectro muito amplo de conteúdo para o conceito de título legítimo de aquisição de domínio, admitindo, como tais, certos títulos de aquisição de sesmarias em comisso e até de aquisição de simples posses dos antecessores. 
A partir dessa manobra, o Regulamento conseguiu ampliar o campo de abrangência do $\S 2^{\circ}$ do art. $3^{\circ}$ da Lei, diminuindo os dos $\S \S 3^{\circ}$ e $4^{\circ}$ do mesmo artigo. Feito isso, pôde estabelecer a desnecessidade de revalidação e de legitimação para uma enormidade de casos de sesmarias e outras concessões incursas em comisso e de simples posses cujos segundos ocupantes da terra tinham algum título formal de aquisição.

Como se pode observar do seu art. 23, para efeitos práticos, o Regulamento igualou aos titulares de sesmarias (e outras concessões) devidamente confirmadas e não incursas em comisso quem, naquele momento, tinha apenas título legítimo de aquisição de direitos sobre sesmarias em comisso e mesmo de aquisição de simples posse. Estabeleceu que eles não precisavam de revalidação, nem de legitimação, nem de novos títulos para terem reconhecidos seus domínios, exatamente como os titulares de sesmarias não incursas em comisso.

Da maneira como o Regulamento de 1854 estendeu o conceito de título legítimo de aquisição de domínio a certos documentos translativos de sesmarias não confirmadas e mesmo de simples posses, pôde diminuir a quantidade de hipóteses de sesmarias em comisso que careciam de revalidação e de posses que precisavam ser legitimadas somente para os seguintes casos:

Art. 24. Estão sujeitos á legitimação:

$\S 1^{\circ}$ As posses, que se acharem em poder do primeiro occupante, não tendo outro titulo senão a sua occupação.

$\S 2^{\circ}$ As que, posto se achem em poder de segundo occupante, não tiverem sido por este adquiridas por titulo legitimo.

$\S 3^{\circ}$ As que, achando-se em poder do primeiro occupante até a data da publicação do presente Regulamento, tiverem sido alienadas contra a prohibição do Art. 11 da Lei $\mathrm{n}^{\circ} 601$ de 18 de Setembro de 1850.

$[\ldots]$

Art. 27. Estão sujeitas á revalidação as sesmarias, ou outras concessões do Governo Geral, ou Provincial que, estando ainda no dominio dos primeiros sesmeiros, ou concessionarios, se acharem cultivadas, ou com principio de cultura, e morada habitual do respectivo sesmeiro, ou concessionario, ou de quem o represente, e que não tiverem sido medidas, e demarcadas.

Exceptuão-se porêm aquellas sesmarias, ou outras concessões do Governo Geral, ou Provincial, que tiverem sido dispensadas das condições acima exigidas por acto do poder competente; e bem assim as terras concedidas á Companhias para estabelecimento de Colonias, e que forem medidas e demarcadas dentro dos prazos da concessão. 


\section{FALHAS NO INÍCIO DO RECONHECIMENTO JURÍDICO [...]}

Desse modo, restringiram a necessidade de legitimação de posse aos primeiros ocupantes da terra e aos segundos ocupantes que não tivessem adquirido sua posse, até a data da publicação do Regulamento, por título que habilitasse também a aquisição do domínio.

Interessante a redação dos $\S \S 3^{\circ}$ e $4^{\circ}$ do art. $3^{\circ}$ da Lei, não considerando essas terras devolutas se as sesmarias e outras concessões em comisso fossem revalidadas ou as posses legitimadas.

Mas essas situações de concessões em comisso a revalidar e de posses a legitimar não poderiam perdurar indefinidamente. Por isso, o art. $7^{\circ}$ mandou o governo marcar os prazos dentro dos quais deveriam ser medidas as terras adquiridas por posses ou por sesmarias, ou outras concessões, que estivessem pendentes de medição. Como sanção, o art. $8^{\circ}$ reputava caído em comisso os possuidores que deixassem de proceder à medição nos prazos marcados. Ademais, o art. 11 obrigava esses posseiros a tirar, junto às repartições provinciais, títulos dos terrenos que lhes ficassem pertencendo por força das disposições da Lei de Terras sobre legitimação de posses e revalidação de sesmarias e outras concessões incursas em comisso. Hipóteses estas que, conforme analisado acima, foram muito reduzidas pelo Regulamento. Ainda assim, depois, na prática, não foram adequadamente executados os mecanismos legais previstos para constranger os particulares a legitimar suas posses ou revalidar suas sesmarias ou outras concessões em comisso.

\section{TERRAS DEVOLUTAS E PROCEDIMENTOS PARA SUA IDENTIFICAÇÃO}

A Lei n. ${ }^{\circ} 601$ definiu as terras devolutas por exclusão:

Art. $3^{\circ}$ São terras devolutas:

$\S 1^{\circ}$ As que não se acharem applicadas a algum uso publico nacional, provincial, ou municipal.

$\S 2^{\circ}$ As que não se acharem no dominio particular por qualquer titulo legitimo, nem forem havidas por sesmarias e outras concessões do Governo Geral ou Provincial, não incursas em commisso por falta do cumprimento das condições de medição, confirmação e cultura.

$\S 3^{\circ}$ As que não se acharem dadas por sesmarias, ou outras concessões do Governo, que, apezar de incursas em commisso, forem revalidadas por esta Lei.

$\S 4^{\circ}$ As que não se acharem occupadas por posses, que, apezar de não se fundarem em titulo legal, forem legitimadas por esta Lei. 
Com exceção do $\S 1^{\circ}$, todos os outros parágrafos já foram analisados ao longo deste artigo.

Recapitulando, não eram terras públicas, muito menos devolutas, as mencionadas no $\S 2^{\circ}$, porque reconhecidas como perfeitamente integradas ao domínio particular.

Quanto às terras mencionadas nos $\S \S 3^{\circ}$ e $4^{\circ}$, curiosa a situação delas. Se não eram terras devolutas, também ainda não eram exatamente terras objeto de propriedades particulares, porque dependentes da legitimação das posses ou da revalidação das sesmarias e das outras concessões. Discutível a situação delas: ou eram terras públicas em vias de privatização, ou eram terras já no domínio particular, mas ainda sem títulos de propriedade em favor dos respectivos possuidores e beneficiários de sesmarias ou outras concessões incursas em comisso. Augusto Teixeira de Freitas (1876, p. 61-62) optou pela primeira hipótese, considerando-as terras publicas, mas não devolutas, porque já estavam na posse de particulares, quando da promulgação da Lei de Terras do Império. Relembrando que esta, conquanto tenha proibido o apossamento de terras daquele momento em diante, procurou regularizar a situação das terras de qualquer forma já possuídas por particulares. As terras ainda não apossadas eram as terras devolutas.

Todavia, ao trabalhar essas definições da Lei, o Regulamento (art. 22 ao 27) conseguiu alargar o alcance do $\S 2^{\circ}$, ao mesmo tempo que estreitou o dos $\S \S 3^{\circ}$ e $4^{\circ}$. Assim, ampliou bastante a quantidade de terras já consideradas perfeitamente no domínio privado, ao mesmo tempo em que reduziu a quantidade de posses que necessitavam de legitimação ou de revalidação de sesmarias ou outras concessões.

Volvendo ao $\S 1^{\circ}$, a Lei não considerou devolutas as terras que estivessem afetadas a algum uso público, fosse nacional, provincial, ou municipal. Eis alguns exemplos constantes das Ordenações Filipinas: estradas, ruas, praças e portos (Liv II, tít. 26). Assim, terras devolutas eram as terras do Império não empregadas em alguma finalidade pública e não apossadas por particulares.

Resumindo, segundo a Lei de 1850, terras devolutas eram as terras públicas não afetadas a algum uso público, nem possuídas naquele momento por particulares. Das terras possuídas por particulares, muitas foram plenamente reconhecidas no domínio privado $\left(\S 2^{\circ}\right)$, enquanto as outras foram consideradas revalidáveis $\left(\S 3^{\circ}\right)$ ou legitimáveis $\left(\S 4^{\circ}\right)$. 


\section{FALHAS NO INÍCIO DO RECONHECIMENTO JURÍDICO [...]}

Era necessário, portanto, localizar, identificar e demarcar essas terras públicas que não estavam destinadas a algum uso público, nem eram possuídas por particulares, as designadas pela Lei como terras devolutas. Ao mesmo tempo, era igualmente necessário ter uma noção de quais seriam as terras revalidáveis e as legitimáveis, porque se as revalidações e legitimações não fossem cumpridas, nos prazos concedidos, cairiam definitivamente em comisso (art. $8^{\circ}$ da Lei).

Quanto a isso, o art. 10 da Lei determinara ao Governo prover "o modo pratico de extremar o dominio publico do particular, segundo as regras acima estabelecidas, incumbindo a sua execução ás autoridades que julgar mais convenientes, ou a commissarios especiaes $[\ldots]^{\prime \prime}$.

Nessa vereda, o capítulo III do Regulamento foi nominado "Da revalidação, e legitimação das terras, e modo pratico de extremar o domínio publico do particular". No entanto, é quase inteiramente dedicado à revalidação e à legitimação. Mesmo do art. 28 ao 58, que disciplinam o procedimento, voltou-se quase exclusivamente à identificação e medição de terras revalidáveis e legitimáveis, relegando a de terras devolutas somente ao último artigo, como se fosse questão sem maiores dificuldades e possível de ser enfrentada na forma disciplinada pelo Capítulo II, "Da medição das Terras Publicas”.

Sobre o procedimento, previa que os Presidentes das Províncias deveriam exigir dos Juízes e Delegados informação circunstanciada sobre a existência ou inexistência de posses e de sesmarias ou outras concessões sujeitas à legitimação e revalidação (art. 28). Para os Municípios onde se verificasse a necessidade de legitimações ou revalidações, os Presidentes das Províncias nomeariam um Juiz Comissário de medições (art. 30). Seriam, então, marcados prazos para a medição das terras sujeitas à legitimação ou revalidação (art. 32). Havia possibilidade de prorrogação desses prazos (art. 33), o que estava em consonância com o art. $7^{\circ}$ da Lei.

Todavia, o diploma regulamentar impôs um sério obstáculo ao Poder Público: “Art. 36. Os Juizes Commissarios não procederão á medição alguma sem preceder requerimento de parte: o requerimento deverá designar o lugar, em que hesita a posse, sesmaria, ou concessão do Governo, e os seus confrontantes.”.

O dispositivo proibiu o Estado de tomar a iniciativa em verificar a existência de terras em situação de legitimação de posses ou revalidação de sesmarias e outras concessões. Deixou-o, portanto, à mercê da vontade do particular em regularizar suas terras. O único mecanismo para constranger o particular era a sanção do comisso, após o decurso dos prazos concedidos (art. $8^{\circ}$ da Lei). 
Assim, os particulares deveriam formular seus requerimentos nos prazos marcados para as medições (arts. 32 e 36 do Regulamento), findos os quais os Comissários informariam os Presidentes das Províncias "do estado das medições, e do numero das sesmarias, e posses, que se acharem por medir, declarando as causas, que houverem inhibido a ultimação das medições" (art. 56 do Regulamento). À vista dessas informações, os Presidentes das Províncias deliberariam sobre a justiça e conveniência da concessão de novo prazo (art. 57).

Expirados todos os prazos e prorrogações possíveis (arts. 32, 33 e 57), deveria ser declarada a sanção do comisso, regulamentada nos seguintes termos:

\begin{abstract}
Art. 58. Findos os prazos, que tiverem sido concedidos, os Presidentes farão declarar pelos Commissarios aos possuidores de Terras, que tiverem deixado de cumprir a obrigação de as fazer medir, que elles teem cahido em commisso, e perdido o direito a serem preenchidos das terras concedidas por seus titulos, ou por favor da Lei $\mathrm{n}^{\mathbf{o}}$ 601 de 18 de Setembro de 1850, e desta circumstancia farão as convenientes participações ao Delegado do Director Geral das Terras Publicas, e este ao referido Director, a fim de dar as providencias para a medição das terras devolutas, que ficarem existindo em virtude dos ditos commissos.
\end{abstract}

Aparentemente, era necessário um ato formal de declaração do caimento em comisso. E, só depois disso, teriam início "as providencias para a medição das terras devolutas, que ficarem existindo em virtude dos ditos commissos". Como mais nada foi estipulado, é de se supor que devesse seguir a normatização do Capítulo II, "Da medição das Terras Publicas", que mandava dividir as Províncias, onde houvesse terras devolutas, "em tantos districtos de medição, quantos convier" (art. 10), chefiados por um "Inspector Geral das medições" (art. 11).

Mas nada impedia, desde logo, as medições dos enormes espaços de terras desocupados que independiam da declaração de comisso para serem considerados devolutos, na forma do Capítulo II. As medições começariam pelas terras que se reputassem devolutas e que não estivessem encravadas por posses (art. 17 do Regulamento). Não obstante, se o Governo julgasse conveniente, poderia "mandar proceder á medição das terras devolutas contiguas tanto ás terras, que se acharem no dominio particular, como ás posses sujeitas á legitimação, e sesmarias, e concessões do Governo sujeitas á revalidação, respeitando os limites de humas, e outras" (art. 18). Segundo o art. 14 da Lei e o art. 12 do Regulamento, as medições seriam feitas identificando as áreas de terras devolutas, sempre que possível, em forma de quadrados. 


\section{FALHAS NO INÍCIO DO RECONHECIMENTO JURÍDICO [...]}

Caso algum particular se sentisse prejudicado, poderia apresentar ao Agrimensor petição. Porém, isso não impedia o prosseguimento dos trabalhos do Inspetor do distrito. Ao final, tudo seria remetido ao Juiz Municipal, se o peticionário prejudicado fosse possuidor ou sesmeiro não sujeito à legitimação ou revalidação; ou aos Juízes Comissários criados pelo art. 30 do Regulamento, se o peticionário fosse possuidor ou sesmeiro sujeito à revalidação ou legitimação. Em seguida, seria dada vista aos opoentes, por cinco dias, para deduzirem seus embargos perante estas autoridades (art. 19).

A decisão deveria sempre observar se as posses eram anteriores ou posteriores à publicação do Regulamento. Se estabelecidas depois, não poderiam ser respeitadas (art. 20). Se estabelecidas antes, deveriam ser consideradas as extensões de terras cultivadas, ou com princípios de cultura, e morada habitual, antes do início da vigência da Lei (arts. $4^{\circ}$ e $5^{\circ}$ da mesma). $\mathrm{O}$ art. $6^{\circ}$ não admitia simples roçados, derribadas ou queimas de matos ou campos, levantamentos de ranchos e outros atos de semelhante natureza, quando não acompanhados da cultura efetiva e da morada habitual. No mesmo sentido, o art. 37 do Regulamento rejeitava "simples roçados, derribadas, ou queimas de matos, e outros actos semelhantes". Marés critica que tais dispositivos visaram prejudicar pequenos posseiros e favorecer a concentração fundiária entre os grandes fazendeiros, porque "a produção exigida pela lei era a voltada para o mercado, não a de simples subsistência ou baseada na coleta e na caça” (2003, p. 68).

Em outro trabalho, o autor destas linhas afirmou equivocadamente que "o decreto regulamentar da lei não disciplinou a discriminação de terras" (2012, p. 385). Na verdade, a regulamentação acima analisada era razoavelmente apta, pelo menos naquele primeiro momento, para extremar as terras devolutas das terras particulares. Mas isso deveria ter sido feito com rapidez, a fim de evitar o subsequente apossamento de terras devolutas. Não foi o que aconteceu, acarretando o prosseguimento de um quadro fundiário cada vez mais caótico.

\section{INEXISTÊNCIA DE UM SISTEMA REGISTRAL IMOBILIÁRIO MINIMAMENTE SEGURO, INÉRCIA DO PODER PÚBLICO E PERPETUAÇÃO DAS FALHAS DA LEGISLAÇÃO IMPERIAL DE TERRAS}

Pior do que a normatização, traiçoeira em alguns pontos, da Lei e do Regulamento foi a lentidão do Império, tanto em identificar e demarcar as terras devolutas, como a pôr em prática os mecanismos disponíveis para constranger os particulares a regularizar suas posses legitimáveis e a revalidar suas sesmarias e outras concessões em comisso. Tudo isso fez com 
que os antigos problemas persistissem e surgissem outros, decorrentes não apenas das falhas da lei, como da sua inexecução.

Citando Handelmann, Lígia Osório Silva (1996, p. 178) observa que, durante anos, a legislação de terras do Império foi letra morta. Constatou que até 1861, "quase nada havia sido feito em matéria de demarcação de terras e pouquíssimo em matéria de colonização". Por outro lado, o apossamento de terras devolutas continuou desenfreadamente e, quando conveniente, acompanhado de subterfúgios para a apropriação ilegal dessas terras por particulares (1996, p. 180).

Para compreensão disso é necessário ter em vista que, na maior parte do país, os fazendeiros ainda não estavam interessados na constituição de propriedades privadas da terra, perfeitamente delimitadas. Bastava-lhes simplesmente a posse, que poderia ser ampliada, quando necessário, com a incorporação de terras devolutas contíguas ou coagindo pequenos posseiros vizinhos. A terra, por si só, não tinha valor. Valia mais o empreendimento que a explorasse em largas extensões e, para tanto, dada a falta de mão de obra, era necessário ter escravos. Mesmo em termos de bens privados, a palavra "fazenda" ainda guardava como significado mais usual o de conjunto de bens, não o de propriedade de terras rurais, como acontece hoje.

Até aquele momento, o livre apossamento de terras, associado ao trabalho escravo, é que vinha possibilitando a formação de grandes fazendas agrárias. As terras tinham pouco valor no Brasil, porque não havia meios tecnológicos a fazê-la produzir, exigindo a utilização de mão de obra em larga escala, mas esta não era farta, o que obrigava à importação de escravos a um elevado custo. Assim, o que tinha alto valor de mercado eram os escravos, não a terra. Interessava muito mais ter garantido o direito de propriedade sobre o escravo do que sobre a terra.

Só a partir da promulgação da Lei do Ventre Livre, em 1871, retomaram-se as discussões sobre a imigração e reacendeu-se a preocupação com o apossamento de terras devolutas por imigrantes e escravos libertos. Brotou o temor, entre os grandes fazendeiros, de não mais conseguirem mão de obra, uma vez que a maior parte dos trabalhadores iria preferir labutar para si mesma, em seus próprios estabelecimentos rurais, caso o apossamento de terras devolutas não fosse efetivamente estancado. Um país tomado por pequenos proprietários rurais, que optassem pela agropecuária de subsistência e de abastecimento do mercado interno, significaria a derrocada da economia agroexportadora brasileira, o que também não interessava ao Governo (GRANDE JÚNIOR, 2012, p. 42-43). José de Souza Martins (1979, 


\section{FALHAS NO INÍCIO DO RECONHECIMENTO JURÍDICO [...]}

p. 68) lembra que, "durante mais de um século, a 'falta de braços para a lavoura' foi a mais reiterada reclamação dos fazendeiros, mesmo em momentos de crise de superprodução e de baixa de preços do café".

Lígia Osorio Silva (1996, p. 191) entende que tais acontecimentos forçaram o Governo a reorganizar o Serviço de Terras e Colonização, em 1876. Porém, ainda não conseguindo agilizar a demarcação das terras particulares, a Administração Imperial "resolveu adotar a tática de se preocupar apenas com a demarcação das terras devolutas, lá onde sua existência fosse inquestionável" (1996, p. 192).

\footnotetext{
Ainda assim, o quadro apresentava-se deveras desanimador. Dez anos depois da reforma do serviço de terras havia comissões de medição de terras funcionando em apenas seis províncias: Pernambuco, Bahia, São Paulo, Espírito Santo, Minas Gerais e São Pedro do Rio Grande do Sul. Mesmo nessas províncias pouco estava sendo feito. Nas demais as informações eram poucas e inexatas. (1996, p. 193)
}

Apenas o Rio Grande do Sul pôde ser considerado uma exceção. As informações colhidas e os relatórios elaborados surtiam algum resultado, pois houve mais processos de revalidação de sesmarias e de legitimação de posses do que nas outras províncias. Ainda assim, por mais que revalidassem, legitimassem e vendessem terras, sempre havia tantas outras mais aguardando regularização (SILVA, 1996, p. 200-203).

Com relação à Província de Goiás, Maria Amélia Garcia de Alencar (1993, p. 3136) constatou que o cumprimento da legislação de terras pouco interessava às elites agrárias. "Dedicada, em geral, à pecuária extensiva, melhor seria, dentro da sua ótica, deixar em aberto a possibilidade de incorporação de novas terras, sem qualquer formalidade ou despesas, sempre que isto se fizesse necessário”. Apesar de, no início de 1855, o Governo Central ter requisitado medidas e informações para o cumprimento da legislação, os trabalhos de registro das terras possuídas a qualquer título (Registro Paroquial) só se iniciaram ao final de 1856, encerrando-se o último prazo em $1^{\circ}$ de abril de 1860. De um modo geral, a atuação das repartições públicas de terras, em Goiás, foi bastante contida e os dispositivos do Regulamento sobre identificação de terras públicas e devolutas surtiram efeito muito pequeno durante todo o período imperial. O próprio Presidente da Província, em 1873, reconhecia: "quase nada se tem praticado a respeito das terras públicas", embora fosse do conhecimento das autoridades a existência de muitas terras devolutas, conforme relatórios elaborados quinze anos antes. Não tendo havido demarcação, não chegou a ocorrer a venda de terras devolutas, pelo menos não em hasta pública. Igualmente falhos foram os trabalhos de revalidação de 
sesmarias e legitimação de posses. Maria Amélia Garcia de Alencar encontrou menções a apenas setenta e três posses legitimadas até 1862 .

"Permaneceram sem mapeamento as terras devolutas e, consequentemente, continuavam as invasões e apropriações sobre elas, chegando nessa situação o problema quando da Proclamação da República.” (SANCHES, 2008, p. 27). Destarte, passados quase quarenta anos da promulgação da Lei Imperial de Terras, a República herdou uma situação fundiária tão caótica quanto a que o Império havia herdado da Colônia. Os desmandos locais, as usurpações de terras devolutas e os diversos expedientes, para dar uma aparência legal às supostas "propriedades", continuavam sendo as formas práticas de acesso à terra em Goiás e na maior parte do país (ALENCAR, 1993, p. 36).

A Constituição de 1891 transferiu a maioria das terras devolutas para os Estados, deixando-as definitivamente à mercê das oligarquias regionais. Os Estados mantiveram, em suas leis, os princípios básicos e a maioria das regras da Lei de Terras de 1850, ao mesmo tempo em que herdaram a mesma falta de iniciativa em cumpri-las perante os especuladores e grandes fazendeiros. Essas legislações estaduais serviam apenas para impedir o acesso à propriedade da terra à grande massa de iletrados e desamparados de assessoramento jurídico, enquanto os afortunados e conhecedores das brechas legais continuavam a avançar sobre terras devolutas.

Completando o caos fundiário, por várias décadas simplesmente não existiu em nosso país um sistema registral imobiliário minimamente seguro.

Quanto a isso, cabe preliminarmente explicar que o Registro Paroquial não constituía, nem era um assentamento de propriedades imobiliárias, muito menos registro de transcrição de títulos de domínio ou de transferência da propriedade. O texto da lei deixa claro que era um registro tão somente "das terras possuídas" (art. 13). Além disso, tinha por base meramente "as declarações feitas pelos respectivos possuidores", embora o citado dispositivo legal determinasse ao Governo prever multas e penas para quem fizesse declarações inexatas ou não as prestasse nos prazos a serem marcados. O Regulamento não fugiu dessa orientação e nominou seu capítulo IX como "Do registro das terras possuídas". Obrigou ao registro "todos os possuidores de terras, qualquer que seja o titulo de sua propriedade, ou possessão" (art. 91).

Assim, o Registro Paroquial consistiu num grande trabalho de cadastramento das terras possuídas por particulares, com ou sem título. Foi criado com o intento de nortear os trabalhos de identificação e demarcação das terras particulares, das terras legitimáveis e 


\section{FALHAS NO INÍCIO DO RECONHECIMENTO JURÍDICO [...]}

revalidáveis e das terras devolutas. O registro geral das terras possuídas orientaria o Império a localizar as terras que dependiam de legitimação de posse ou de revalidação de sesmarias ou concessões, bem como a identificar e demarcar as terras naquele momento desocupadas e não aplicadas a qualquer uso publico, ou seja, as consideradas devolutas, segundo o art. $3^{\circ}$ da Lei de Terras.

Contudo, dada a inação do Império em prosseguir com as tarefas subsequentes, o Registro Paroquial ganhou, no decorrer das décadas, a importância de ser, na maioria das regiões, o único legado do Império em matéria de cumprimento da Lei das Terras. Essa ausência de outras informações proporcionou a deturpação do significado do Registro Paroquial, levando alguns a acreditar que se tratava de registro de propriedades. Hoje isso é impensável, pois a questão se encontra pacificamente superada pela jurisprudência. Bastante representativo é o seguinte julgado do Supremo Tribunal Federal:

RECURSO EXTRAORDINÁRIO. AÇÃO DISCRIMINATORIA. REGISTRO PAROQUIAL. NÃO INDUZ PROPRIEDADE. É MEIO PROBANTE DO FATO DA POSSE. [...].

(RE 79828, Relator(a): Min. NÉRI DA SILVEIRA, Primeira Turma, julgado em 06/03/1989, DJ 08-06-1990 PP-05241 EMENT VOL-01584-01 PP-00149)

Retornando aos pecados originais da legislação imperial de terras, o reconhecimento do pleno domínio particular a partir da posse, acompanhada de um título legítimo de sua aquisição, foi uma solução imediatista, que visava beneficiar, da forma menos onerosa, o maior número possível de pessoas que já tinham fazendas constituídas naquele momento. Ao mesmo tempo, a legislação de terras do Império objetivava dificultar a formação de novas fazendas, onerando-as com o custo de compra da terra. Muito claro o propósito de dificultar a vida de quem ainda não tinha obtido acesso à terra, mas evitando causar transtornos aos que já tinham.

A fórmula adotada pela legislação teve potente eficácia no seu momento inicial, mas carecia de segurança jurídica para o futuro. Se não obrigava à expedição de novos títulos, deveria, pelo menos, ter exigido o registro ou transcrição deles para as subsequentes transferências de domínio. Mas não houve a edição das necessárias normas legais em tal sentido, de modo que o domínio sobre a terra pôde continuar a ser transferido de uma pessoa para outra consoante previsto nas Ordenações Filipinas, ou seja, mediante apenas a tradição, acompanhada de um título ao qual não era preciso atribuir publicidade. Portanto, a Lei de Terras e seu Regulamento reconheceram o domínio particular absoluto sobre a terra, ou seja, o 
poder incondicional do indivíduo sobre ela; mas capengaram na concepção da propriedade privada abstrata da terra, ou seja, na adequada normatização da relação jurídica entre quem tem o domínio incondicionado da terra e as demais pessoas que compõem a sociedade. Para tanto, seria necessário dar certeza e publicidade ao título de domínio, de modo a permitir ao restante do corpo social saber inequivocamente quem, a cada momento, é o titular do direito de dominar com exclusividade uma área da superfície do globo terrestre localizada no território do país.

O primeiro passo nesse sentido seria a outorga de um título de domínio pelo Estado, conferindo ou reconhecendo o domínio exclusivo da coisa a uma determinada pessoa e em detrimento de todas as outras, até mesmo do próprio Estado. Ou seja, substituir os precedentes títulos passados entre particulares por novos e inequívocos títulos outorgados pelo Estado, permitindo a este, inclusive, um controle do que foi reconhecido estar no domínio privado e do que ainda estava no patrimônio público originário. Essa era uma medida inevitável em um país com dimensões continentais e com vastas terras ainda no domínio público, como o Brasil. Poderia a medida ser dispensada apenas em países territorialmente pequenos e nos quais a maioria das terras já se encontrasse no domínio privado, como, por exemplo, Portugal.

O segundo passo, este inevitável em qualquer país, seria a constituição de um sistema organizado capaz de dar publicidade sobre quem é, a cada instante, o titular do domínio exclusivo sobre cada área da superfície do planeta, em detrimento de todas as outras pessoas. Ou seja, a constituição de um aparelhamento que possibilitasse ao público o conhecimento acerca de todas as transferências de titularidade do domínio sobre a terra. Uma forma de fazer isso seria com a criação de cartórios com atribuições de registro, para consulta pública, de todas as transferências de propriedade da terra, estabelecendo-se que tais transferências só ocorreriam com o registro.

Adotados os dois passos acima, poder-se-ia falar em propriedade privada abstrata da terra, garantidora do domínio privado absoluto, tanto em face do Estado como de outros particulares. Domínio absoluto, na acepção de não sujeito a condições, como, por exemplo, o cultivo. E propriedade abstrata no sentido de ser perfeitamente demonstrável apenas pelo título, independentemente da exteriorização de atos concretos do indivíduo sobre a coisa.

Mesmo que no Brasil não tenha sido exigido, em regra, o primeiro passo, ou seja, a expedição de novos títulos; dever-se-ia, pelo menos, ter seguido o segundo, ou seja, instituído a obrigatoriedade do registro ou transcrição dos antigos títulos para as subsequentes 


\section{FALHAS NO INÍCIO DO RECONHECIMENTO JURÍDICO [...]}

transferências de domínio. Se tivessem imediatamente criado cartórios com atribuição de registro de imóveis e estabelecida a obrigatoriedade desse registro, sempre com expressa menção ao título ou registro antecedente, seria possível, hoje, na maioria dos casos, averiguar a validade da origem do domínio particular mediante consulta da cadeia dominial registrada no cartório competente.

Mas nada disso foi feito, apesar de, na época, em face das grandes transformações econômicas ocorridas, já ser admitida a ineficiência da tradição como mecanismo de transferência da propriedade imóvel.

Somente com o Código Civil de 1916 o registro foi inequivocamente reconhecido como elemento intrínseco da transferência da propriedade imobiliária. Apenas sessenta e seis anos depois da Lei de Terras do Império é que se conseguiu fulminar, do direito brasileiro, a transferência de domínio imobiliário destituída de publicidade e eficácia erga omnes. Fê-lo o Código Civil ao enumerar taxativamente os modos de aquisição da propriedade imobiliária (art. 530), ao disciplinar a aquisição da propriedade pela transcrição de título (art. 531 a 533) e ao traçar as linhas gerais do Registro de Imóveis (art. 860, parágrafo único).

Acima foram apontados os dois requisitos necessários para a concretização da propriedade privada absoluta e abstrata sobre a terra: (i) reconhecimento pelo Estado de um título inequívoco de domínio oponível contra todos; e (ii) publicidade sobre quem, a cada momento, é o titular dessa propriedade. A normatização supramencionada do Código Bevilaqua cuidou apenas do segundo requisito, nada dispondo sobre o primeiro. Tanto é verdade que o Código exigiu a transcrição, não do título de domínio, mas apenas do título de transferência da propriedade.

Em razão disso, entendeu-se que as transmissões de domínio de imóveis posteriores a 31 de janeiro 1916 exigiam registro imobiliário, ao passo que as anteriores não, porque já perfeitas e acabadas, ou seja, atos jurídicos perfeitos. Assim, os Cartórios simplesmente registravam o documento de transmissão do domínio, sem indicação de qual era o título que amparava o suposto domínio do alienante e, muito menos, se esse título era reconhecido pelo Estado como de domínio. Várias cadeias registrais imobiliárias tiveram início com tal falha, mencionando, quando muito, apenas o último título da cadeia dominial anterior ou pré-registral. Tal omissão não permite verificar, mediante apenas consulta aos registros do cartório imobiliário, a validade da origem do domínio particular. Nesses casos, o registro imobiliário não dá certeza absoluta sobre o domínio privado, porque não se sabe qual a origem dele. Com relação a isso, Júlia Rosseti Picinin Arruda Vieira (2009, p. 132) 
comenta: "Segundo Bevilaqua, o objetivo era fazer da transcrição um modo de tradição dos imóveis, sem que ela purificasse as nulidades.”.

Falha ainda pior, nesses primórdios, era a da não obrigatoriedade de encadeamento ou continuidade entre os registros. Essa questão só teve sua disciplina jurídica aperfeiçoada com o Decreto n. ${ }^{\circ}$ 18.542, de 1928, que baixando o regulamento para execução dos registros públicos, estabeleceu: “Art. 206. Si o immovel não estiver lançado em nome do outorgante o official exigirá a transcripção do titulo anterior, qualquer que seja a sua natureza, para manter a continuidade do registro.". Todavia, previu uma exceção para os domínios transmitidos anteriormente à obrigatoriedade de registro:

Art. 234. Em qualquer caso não se poderá fazer transcripção ou inscripção sem prévio registro do titulo anterior, salvo se este não estivesse obrigado a registro, $\underline{\text { segundo o direito então vigente, }}$ de modo a assegurar a continuidade do registro de cada predio, entendendo-se por disponibilidade a faculdade de registrar alienações ou onerações dependentes assim, da transcripção anterior. [sublinhou-se]

Júlia Rosseti Vieira (2009, p.160) sintetiza a interpretação que prevaleceu na prática:

Segundo Serpa Lopes, o problema deveria ser resolvido de acordo com o momento em que o título anterior tivesse sido elaborado. Se antes do Código Civil, ele não precisava ser transcrito, já que no momento de sua formação a legislação vigente não exigia seu registro. Se elaborado após a promulgação do Código Civil, sua transcrição era obrigatória.

Em razão de tudo isso, Soriano Neto criticou a adoção do princípio da continuidade no Brasil, pois ao que ele mandava conferir continuidade, oficialmente, não tinha qualquer começo (VIEIRA, 2008, p. 159). Apesar das inovações trazidas pela Lei n. ${ }^{\circ}$ 6.015, de 1973, esse problema persiste até hoje. A exceção é o Registro Torrens, instituído em 1890, mas com caráter facultativo e pouco utilizado na prática.

Se o problema da falta de presunção absoluta de veracidade do Registro Imobiliário Comum pode, em muitos casos, ser solucionado entre particulares mediante a invocação da usucapião, nem sempre isso é possível em face do Estado. Hodiernamente, contra o domínio público não é alegável nem oponível a usucapião. Dispõe o Código Civil: “Art. 102. Os bens públicos não estão sujeitos a usucapião.”. 


\section{FALHAS NO INÍCIO DO RECONHECIMENTO JURÍDICO [...]}

Conquanto a usucapião tenha natureza declaratória, podendo ser reconhecida sua consumação em épocas pretéritas, verifica-se que o obstáculo da imprescritibilidade dos imóveis públicos regride no tempo até a Lei de Terras do Império, relacionando-se com o problema da eterna procrastinação na identificação e demarcação das terras devolutas.

A Constituição de 1988 proibiu a usucapião de imóveis públicos, até mesmo sob as formas constitucionais especiais rural e urbana (art. 183, $\S 3^{\circ}$, e 191, parágrafo único). O Código Civil de 1916 foi confuso quanto à imprescritibilidade dos bens públicos dominicais, instaurando-se grande controvérsia doutrinária e jurisprudencial sobre a questão. Foram necessários o Decreto n. ${ }^{\circ} 19.924$, de 1931, e o Decreto n. ${ }^{\circ} 22.785$, de 1933, para explicitar, o primeiro, a imprescritibilidade das terras devolutas e o segundo a de todas as categorias de bens públicos. Somente para após a vigência desses decretos se obteve consenso sobre a imprescritibilidade dos bens públicos a que se referem. Para o período entre o início da vigência do Código Civil e o desses decretos continuou a divergência sobre a prescritibilidade das terras devolutas e de outros bens públicos dominicais. A questão foi definitivamente encerrada apenas em dezembro de 1963, com a aprovação do verbete n. 340 da Súmula do Supremo Tribunal Federal: "Desde a vigência do Código Civil, os bens dominicais, como os demais bens públicos, não podem ser adquiridos por usucapião.”. A exceção admitida era a usucapião pro labore, criada pela Constituição de 1934, repetida na de 1937, alargada com a de 1946 e pela Emenda Constitucional n. ${ }^{\circ}$ 10, de 1964, e parcialmente reestabelecida com a Lei n. ${ }^{\circ}$ 6.969, de 1981. Antes do Código Civil de 1916 era admitida a prescrição aquisitiva sobre os bens do domínio do Estado, classificação que atualmente abrangeria bens públicos de uso especial e, principalmente, bens dominicais. Todavia, as terras devolutas estavam submetidas a um regramento jurídico especial, do qual brotou a polêmica, nunca solucionada, sobre a prescritibilidade, ou não, desta espécie de bem público. Mas há uma tendência em aceitá-la e os registros paroquiais são admitidos como prova de posse para tanto (GRANDE JÚNIOR, 2012).

Assim, no Brasil, a maioria das propriedades imobiliárias repousa sobre registros cartorários que não dão certeza absoluta sobre a validade do domínio particular. E, em razão de todas as dificuldades jurídicas acima noticiadas, acumuladas ao longo da história, grande celeuma se instaura toda vez que o Poder Público resolve verificar se o domínio particular tem origem válida. Daí a perplexidade e o temor provocados pelo instituto jurídico da discriminação de terras devolutas. 
CONCLUSÕES

À medida que avançava pela América do Sul, o Estado Português, confundindo-se com sua Coroa, adquiria o domínio de todas as terras que hoje compõem o território brasileiro. Ainda não se cogitava em domínio privada absoluto e propriedade abstrata da terra. O direito à utilização da terra era concedido aos particulares através do instituto jurídico das sesmarias, que constituía uma forma de domínio condicionado ao efetivo cultivo e de propriedade que se externava pela continuidade deste.

Com a Independência, as terras antes do domínio da Coroa Portuguesa foram transferidas ao Império do Brasil. Quase concomitantemente, a irreversível realidade do apossamento não autorizado de terras obrigou à suspensão do regime sesmarial e a mentalidade dos novos tempos exigiu a normatização da propriedade privada abstrata sobre a terra. A transição para o contemporâneo sistema de propriedade teve início com a Lei de Terras do Império. Seu Regulamento, principalmente do art. 22 ao art. 27, cujo estudo é muitas vezes negligenciado, teve uma enorme importância naquele momento, com consequências que perduram até hoje, principalmente no que diz respeito ao seu art. 23, que dispensou, em uma série de hipóteses, a expedição de novos títulos, em substituição aos antigos, para o exercício do direito abstrato de propriedade.

A Lei de 1850 reconheceu o domínio privado absoluto sobre as terras objeto de sesmarias e outras concessões governamentais naquele momento não incursas em comisso. $\mathrm{O}$ art. 23 do Regulamento da Lei de Terras dispensou a retirada de novos títulos para tal situação, do que resultou um enorme problema para as gerações futuras, porque, atualmente, se encontra dispersa a documentação sobre concessão, registro, demarcação, medição confirmação e não aplicação de ulterior pena de comisso por interrupção do cultivo.

Questão mais grave criada pelo Regulamento foi a do excessivo alargamento da concepção do título legítimo de aquisição de domínio prescrito pela Lei de Terras. O art. 22 do diploma regulamentador reconheceu o pleno domínio privado a todo possuidor de terras que tivesse adquirido sua posse por algum titulo que, pela legislação da época, também fosse hábil à aquisição do domínio. O domínio privado era reconhecido por tal fórmula tanto em terras concedidas por sesmarias ou outras concessões em comisso, como até mesmo em terras que tinham sido originariamente adquiridas por simples posses dos antecessores. Com graves consequências para o futuro, o art. 23 do Regulamento também dispensou nesta hipótese a expedição de novos títulos em substituição aos antigos, muitos dos quais escritos particulares. 


\section{FALHAS NO INÍCIO DO RECONHECIMENTO JURÍDICO [...]}

A intenção era garantir a propriedade, estabelecendo o mínimo possível de embaraços a quem já possuía terras com algum documento. Todavia, isso armou, para as gerações subsequentes, a arapuca consistente na busca desses antigos documentos translativos de posses, muitos dos quais meros escritos particulares. Igualmente abriu a brecha para a perpetração de fraudes consubstanciada na falsificação de títulos de transferência de posse, com potencial de transferência de domínio, anteriores ao Regulamento da Lei de Terras.

Ambos os problemas foram agravados pela não imediata legitimação das posses e revalidação das sesmarias e outras concessões que se sujeitavam a tais medidas por força dos arts. 24 e 27 do Regulamento. Conquanto este tenha diminuindo muito as hipóteses nas quais isso era necessário, ainda assim o Império não conseguiu levar a cabo as medidas para constranger os particulares a legitimar suas posses ou revalidar suas sesmarias e outras concessões em comisso. Na verdade, não conseguiu nem mesmo identificar inteiramente essas terras já possuídas por particulares, mas que dependiam de revalidação ou legitimação. Muito menos as terras não destinadas a alguma finalidade pública e não possuídas por particulares, ou seja, as terras devolutas propriamente ditas, consoante o art. $3^{\circ}$ da Lei. A omissão possibilitou que, logo em seguida, terras devolutas fossem sorrateiramente apossadas por particulares, prática que continua até nossos dias, porque, na maioria das vezes, a única informação que o Estado tem sobre terras possuídas naquele tempo são as constantes dos registros paroquiais.

Também contribuiu para a formação desse quadro caótico a inexistência, por mais de meio século, de um sistema registral imobiliário obrigatório e minimamente seguro. Quando ele foi criado, a maior parte do estrago na estrutura fundiária brasileira já havia ocorrido. Sem conseguir, de modo descomplicado, retroagir até as origens do domínio privado absoluto sobre a terra, simplesmente se restringiu e ainda hoje se restringe a dar publicidade às situações em que aparentemente os imóveis são de domínio privado. Em razão disso, a maioria dos registros imobiliários não atesta a origem válida do domínio privado sobre a terra, podendo eventualmente incidir sobre terras devolutas e se sujeitar a questionamentos por parte do ente estatal.

\section{REFERÊNCIAS BIBLIOGRÁFICAS}

AGUIAR, Maria do Amparo Albuquerque. Terras de Goiás: estrutura fundiária (1850-1920). Goiânia: Universidade Federal de Goiás, 2003. 
ALENCAR, Maria Amélia Garcia de. Estrutura fundiária em Goiás: consolidação e mudanças (1850-1910). Goiânia: Universidade Católica de Goiás, 1993.

ASCENSÃO, José de Oliveira. Direitos de utilização da terra. Disponível em: $<$ http://www.fd.ul.pt/Portals/0/Docs/Institutos/ICJ/LusCommune/AscensaoJoseOliveira12.pdf >. Acesso em: 10 jul. 2012.

ARONNE, Ricardo. Propriedade e domínio: reexame sistemático das noções nucleares de direitos reais. Rio de Janeiro: Renovar, 1999.

DIAS, Manuel Nunes. O capitalismo monárquico português, 1415-1549: contribuição para o estudo das origens do capitalismo moderno, vol. 1. Coimbra: Faculdade de Letras, 1963.

DINIZ, Maria Helena. Curso de direito civil brasileiro, v. 4: direito das coisas. 13. ed. São Paulo: Saraiva, 1997.

FREITAS, Augusto Teixeira de. Consolidação das leis civis: publicação autorisada pelo governo. 3. ed. Rio de Janeiro: B. L. Ganier, 1876.

GRANDE JÚNIOR, Cláudio. Usucapião quarentenária sobre terras do Estado: fundamentos jurídicos, atualidade e repercussão na questão agrária brasileira. Dissertação de Mestrado. Goiânia: Universidade Federal de Goiás, 2012. Disponível em: <http://mestrado.direito.ufg.br/uploads/14/original_USUCAPI\%C3\%83O_QUARENTEN\%C 3\%81RIA_SOBRE_TERRAS_DO_ESTADO_-_Disserta\%C3\%A7\%C3\%A30_-

_Texto_Final_Revisto_-_Cl\%C3\%A1udio_Grande_J\%C3\%BAnior_(1).pdf >. Acesso em: 22 fev. 2014.

JUNQUEIRA, Messias. O instituto brasileiro das terras devolutas. São Paulo: Lael, 1976.

LUHMANN, Niklas. El derecho de la sociedad. México: Universidad Iberoamericana, 2002.

LIMA, Ruy Cirne. Pequena história territorial do Brasil: sesmarias e terras devolutas. 2. ed. Porto Alegre: Livraria Sulina, 1954.

MARÉS, Carlos Frederico. A função social da terra. Porto Alegre: Sérgio Antônio Fabris, 2003.

MARQUES, Benedito Ferreira. Direito agrário brasileiro. 8. ed. São Paulo: Atlas, 2009.

MARTINS, José de Souza. O cativeiro da terra. São Paulo: Ciências Humanas, 1979.

PORTO, José da Costa. O sistema sesmarial no Brasil. Brasília: Universidade de Brasília, 1979.

RAU, Virgínia. Sesmarias Medievais Portuguesas. Lisboa: Presença, 1982.

SANCHES, Almir Teubl. A questão de terras no início da República: o Registro Torrens e sua (in)aplicação. Dissertação de Mestrado. São Paulo: Universidade de São Paulo, 2008. Disponível em: <http://www.teses.usp.br/teses/disponiveis/2/2139/tde-03072009-161245/>. Acesso em: 22 fev. 2014. 


\section{FALHAS NO INÍCIO DO RECONHECIMENTO JURÍDICO [...]}

SILVA, Lígia Osorio. Terras devolutas e latifúndio: efeitos da lei de 1850. Campinas: Unicamp, 1996.

VARELA, Laura Beck. Das sesmarias à propriedade moderna: um estudo de história do direito brasileiro. Rio de Janeiro: Renovar, 2005.

VIEIRA, Júlia Rosseti Picinin Arruda. Transmissão da propriedade imóvel pelo registro do título e segurança jurídica: um estudo de história do direito brasileiro. Dissertação de Mestrado. São Paulo: Universidade de São Paulo, 2009. Disponível em:

<http://www.teses.usp.br/teses/disponiveis/2/2131/tde-02022012-094543/>. Acesso em: 22 fev. 2014.

Artigo recebido em 25 de janeiro de 2014 e aceito em 22 de abril de 2015 